\title{
GROWTH AND REPRODUCTIVE TRAITS OF FRIESIAN X SANGA CROSSBRED CATTLE IN THE ACCRA PLAINS OF GHANA
}

\section{Obese $\mathrm{FY}^{1^{*}}$, Acheampong $\mathrm{DA}^{1}$ and KA Darfour-Oduro ${ }^{2}$}

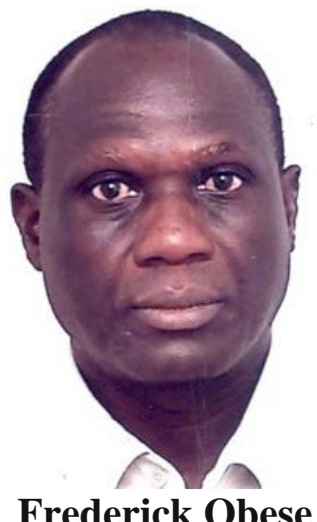

*Corresponding author email: fyobese@yahoo.com

${ }^{1}$ Department of Animal Science, College of Agriculture and Consumer Sciences, University of Ghana, P.O. BOX LG 226, Legon, Ghana

${ }^{2}$ Animal Research Institute, Council for Scientific and Industrial Research, P.O. Box AH 20, Achimota, Ghana 


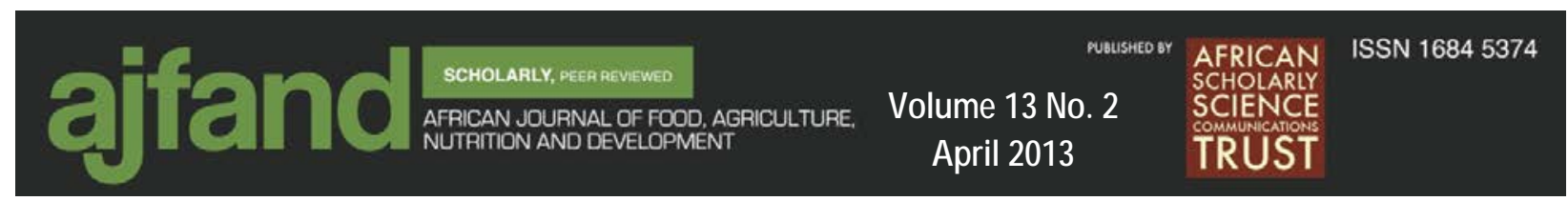

\section{ABSTRACT}

The typical cattle production system in Ghana is predominantly pasture-based. Cattle are grazed all year round on natural pastures with minimal feed supplementation. The animals kept in this production system often experience inadequate nutrition and fluctuating nutrient supply affecting their productivity. There is presently limited information on the growth and reproductive performance of the Friesian x Sanga crossbred cattle (Plate 1) and factors influencing these performance traits. The growth and reproductive performance records of 150 Friesian x Sanga crossbred cattle, kept at the Animal Research Institute station in the Accra Plains of Ghana from April 1993 to October 2009 were evaluated to determine the effect of parity of cow, season of calving and sex of calf on birth weight, weaning weight, growth rate, age at first calving and calving interval. The birth weight and weaning weights of the calves averaged $21.8 \pm 0.5 \mathrm{~kg}$ and $94.2 \pm 3.8 \mathrm{~kg}$, respectively, and were not $(P>0.05)$ affected by sex of calf, parity of cow or season of calving. Parity of cow affected $(P<$ 0.05 ) weight of calf at 12 months. Calf weight at 12 and 18 months averaged $128.0 \pm$ $3.4 \mathrm{~kg}$ and $159.9 \pm 4.5 \mathrm{~kg}$, respectively. Pre-weaning and post-weaning average daily gains were $0.33 \pm 0.02 \mathrm{~kg} /$ day and $0.23 \pm 0.03 \mathrm{~kg} /$ day, respectively, and were not significantly $(P>0.05)$ affected by sex of calf, parity of cow or season of calving. The mean age at first calving was $41.2 \pm 1.2$ months. Calving interval was prolonged averaging $441.6 \pm 10.3$ days and was significantly $(P<0.05)$ affected by parity of cow. Calving interval decreased with increasing parity of cow. The age at first calving and calving interval were not $(P>0.05)$ affected by either sex of calf or season of calving. The growth and reproductive performance of the Friesian $x$ Sanga crossbred cattle was less than optimum. Improving their nutrition could impact, positively, on their productivity through fast growth, increased milk yield and early resumption of ovarian cycles after calving. Thus, results from this study should guide the development of appropriate strategies for increased meat and milk production in Friesian x Sanga crossbred cattle.

Key words: Cattle, grazing, growth, pasture, reproduction 


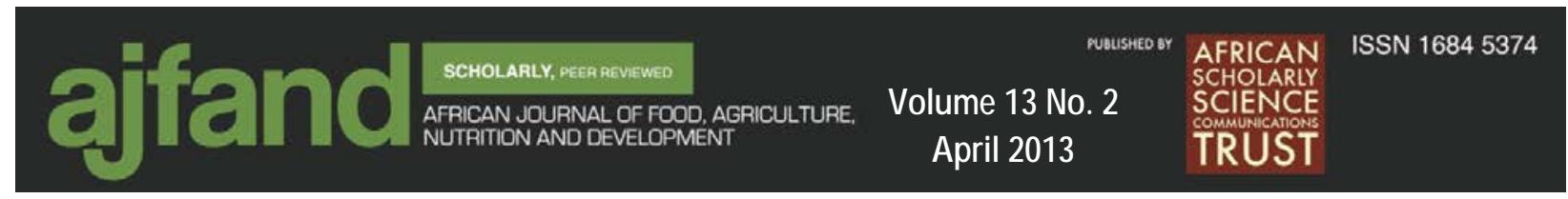

\section{INTRODUCTION}

Livestock production is a major feature of Ghana's agriculture and contributes largely towards meeting food needs, providing drought power, cash income and manure to maintain soil fertility and texture. In Ghana, cattle are mostly raised under the freerange system where they are grazed extensively on communal natural pastures, normally with minimal feed supplementation and health care [1]. The animals are unable to meet their nutritional requirements especially in the dry season when feed is not only scarce but is of poor quality. They, therefore, lose weight and body condition during this period, which affects their growth and reproductive performance [2].

The common breeds of cattle found in Ghana are N'dama, West African Shorthorn, Sokoto Gudali and the Sanga. These are, inherently, slow maturing, low milk producers and have poor reproductive performance [3]. Thus, exotic dairy breeds of cattle such as the Holstein-Friesian were introduced into the country and used as purebreds to improve on the quality and quantity of milk production [4]. These projects were, however, not sustainable due to factors such as high environmental temperature, high humidity, inadequate nutrition and diseases (for example trypanosomiasis, dermatophilosis and heart water) which affected the performance of these exotic breeds. This led to the implementation of crossbreeding programmes involving the use of Holstein-Friesians with indigenous breeds including the Sanga and the West African Shorthorn to improve the adaptive value and productivity of these indigenous breeds.

In 1989, the Animal Research Institute (ARI) of the Council for Scientific and Industrial Research of Ghana embarked on crossbreeding programme using the exotic Friesian and indigenous cattle to evolve a dual-purpose breed for use on the Accra plains in Ghana. Ten Sanga (a cross between a humped zebu and ahumpless cattle such as the West African Shorthorn or the N'dama) cows were mated with acclimatized Friesian bulls.

In the subsequent years, Friesian semen was used for breeding. The $F_{1}$ progeny were inter-mated to produce the Friesian x Sanga crossbred [Plate 1]. There is paucity of information on the growth and reproductive performance of the Friesian x Sanga crossbred and factors that influence these performance traits. An earlier study on the growth traits of Friesian x Sanga calves on the Accra plains did not evaluate the effect of parity of cow on body measurements, growth rate of calves and the reproductive performance of cows [5]. But such information is needed to facilitate the development of measures to improve the performance of the Friesian $x$ Sanga crossbred for meat and milk production. Therefore, the main objective of this study was to assess the growth and reproductive performance of Friesian x Sanga crossbred cattle at the ARI Katamanso Station. 


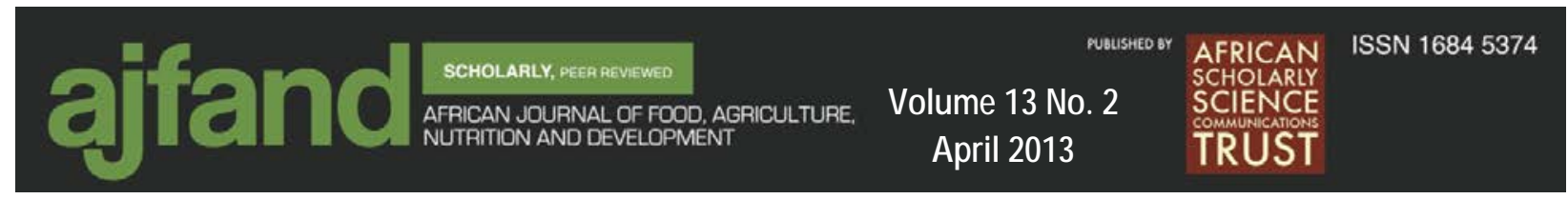

\section{MATERIALS AND METHODS}

\section{Location of study}

The study was conducted at the ARI Katamanso station located at Lat $05^{\circ} 44^{\prime} \mathrm{N}$ and Long $00^{\circ} 08^{\prime} \mathrm{W}$ in the Accra plains of Ghana. The area has a bimodal rainfall pattern with a major wet season occurring from April to July and a minor season from September to November while, the remaining months constitute the dry period. Annual rainfall and temperatures range between $600 \mathrm{~mm}$ and $1000 \mathrm{~mm}$ and $20^{\circ} \mathrm{C}$ and $34^{\circ} \mathrm{C}$, respectively.

\section{Management of animals}

The Friesian x Sanga crossbred cattle were raised under agro-pastoral system to acclimatize them to the management practices on the Accra Plains. They were housed in open kraals and grazed from 05.00 hrs to 10.00 hrs and 13.00 hrs to 16.00 hrs daily on natural pastures. Panicum maximum, Sporobolus pyramidalis and Vertiveria fulvibarbis constitute the dominant grass species in the grazing area while, thickets (mainly browse species) with Griffonia simplicifolia, Baphia nitida and Milletia thoningii were present [6]. Water was provided twice daily; morning and afternoon. They were not given any supplementary feed. The animals were treated against ectoparasites mainly ticks, fleas and mange mites using a pour-on acaricide (Flumethrin 1 $\% \mathrm{~m} / \mathrm{v}$ ) once a month during the dry season and fortnightly in the wet season. Treatment against endo-parasites was done using an anti-helminth, Albendazole $10 \%$ once a month during the dry season and fortnightly in the wet season. They were treated against diseases as the need arose and vaccinated against Contagious Bovine Pleuropneumonia once a year. Cows and their calves were weighed monthly.

\section{Data collection}

Breeding records on 150 Friesian x Sanga crossbred cattle from the ARI Katamanso station were used. The records covered the period from April 1993 to October 2009. Parameters studied included calf birth weight, calf weaning weight at 7 months adjusted to 210 days, pre-weaning average daily gain (growth rate from birth to 7 months), weight of calf at 12 months adjusted to 365 days, weight of calf at 18 months adjusted 540 days, post-weaning average daily gain of calf (growth rate from 7 to 12 months), and age at first calving and calving interval of cow. The effect of sex of calf (male or female), season of calving (major, minor and dry) and parity of cow on these parameters were also determined. Data from the records were edited. After editing there were birth records on 51 calves, 51 records on calves that survived up to weaning. These were used for analysis on pre-weaning average daily gains and weaning weight. There were 46 and 26 records available for analysis on body weight at 12 and 18 months, respectively. The post-weaning average daily gains from weaning to 12 months had 46 records. There were 45 records available for analysis of age at first calving and 167 records for calving interval of cows. 

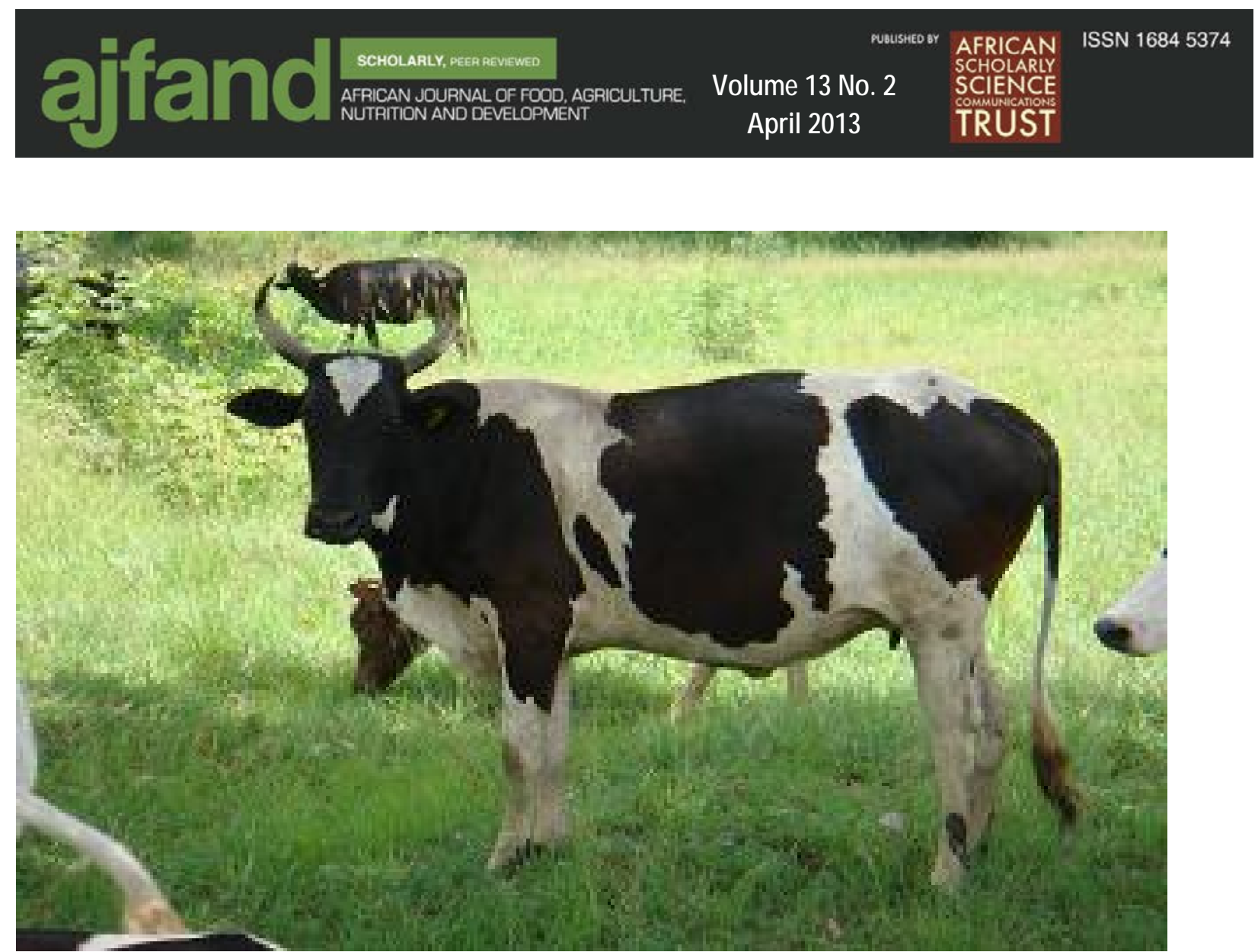

Plate 1: Friesian $x$ Sanga crossbred cow

\section{Statistical analysis}

The data were analysed using General Linear Model (GLM) procedure of the SAS [7]. Differences amongst means of a trait for different factors were analysed by PDIFF/SAS. The statistical model for the growth and reproductive traits was as follows:

$\mathrm{Y}_{\mathrm{ijkl}}=\mu+\mathrm{S}_{\mathrm{i}}+\mathrm{C}_{\mathrm{j}}+\mathrm{P}_{\mathrm{k}}+\mathrm{e}_{\mathrm{ijkl}}$

Where $\mathrm{Y}_{\mathrm{ijkl}}=$ any of the growth and reproductive traits

$\mu=$ overall mean of trait

$\mathrm{S}_{\mathrm{i}}=$ effect of the $\mathrm{i}^{\text {th }}$ sex

$\mathrm{C}_{\mathrm{j}}=$ effect of $\mathrm{j}^{\text {th }}$ season of calving

$\mathrm{P}_{\mathrm{k}}=$ effect of $\mathrm{k}^{\text {th }}$ parity of dam

$\mathrm{e}_{\mathrm{ijkl}}=$ random error associated with each observation

Monthly live weight values were regressed on corresponding ages to obtain growth rates.

Pre-weaning growth rate up to 7 months was estimated as:

Weaning weight - Birth weight No. of days from birth to weaning 


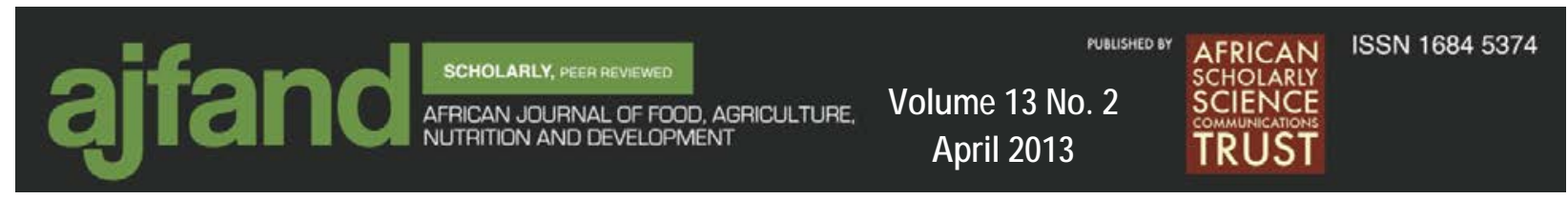

Post-weaning growth rate from weaning (7 months) to 12 months was estimated as:

Weight at 12 months - weaning weight

No. of days from weaning to that age

Age at first calving was estimated as the difference between the day a calf was born and the day it first calved. Calving interval was estimated as the difference between the day a dam calves and its next calving. All the cows with parity beyond three were all grouped as parity four.

\section{RESULTS}

Birth weight, weaning weight and pre-weaning average daily gains

Table 1 shows the effect of sex of calf, parity of cow and season of calving on birth weight, weaning weight at 7 months and pre-weaning average daily gains (from birth up to 7 months) of the Friesian x Sanga calves. The results indicated that, sex of calf, season of calving and parity of cow did not significantly $(\mathrm{P}>0.05)$ affect any of the parameters measured. However, the overall mean birth weight, weaning weight and pre-weaning average daily gains were $21.8 \pm 0.5 \mathrm{~kg}, 94.2 \pm 3.8 \mathrm{~kg}$ and $0.33 \pm 0.02 \mathrm{~kg}$, respectively.

Weight of calf at 12 and 18 months, and post-weaning average daily gains

The mean weight of calf at 12 months and 18 months were $128.0 \pm 3.4 \mathrm{~kg}$ and $159.9 \pm$ $4.5 \mathrm{~kg}$, respectively (Table 2). Parity of cow had a significant $(\mathrm{P}<0.05)$ effect on weight of calf at 12 months but not at 18 months. There was an increase in weight from the first to the fourth parity. Sex of calf and season of calving did not have a significant $(\mathrm{P}>0.05)$ effect on calf weight at 12 months or 18 months. The average post-weaning daily weight gains of calf (7 to 12 months) was $0.23 \pm 0.03 \mathrm{~kg}$ (Table 2 ). This was not significantly ( $P>0.05$ ) affected by sex of calf, parity of cow or season of calving.

\section{Age at first calving and calving interval}

Table 3 shows the effect of sex of calf, parity of cow or season of calving on the age at first calving and calving interval of the Friesian $x$ Sanga cows. The mean age at first calving was $41.2 \pm 1.2$ months. Sex of calf and season of calving did not affect $(\mathrm{P}>0.05)$ age at first calving. The mean calving interval was $441.6 \pm 10.3$ days (14.7 months). Results show that, parity of cow had a significant $(\mathrm{P}<0.05)$ effect on calving interval, which decreased with increasing parity of cow. However, sex of calf and season of calving had no significant $(\mathrm{P}>0.05)$ effect on calving interval.

\section{DISCUSSION}

Birth weight, weaning weight and pre-weaning average daily gains

In this study, the growth and reproductive performance of Friesian x Sanga crossbred cattle grazing mainly natural pasture was evaluated. The birth weight of a calf affects

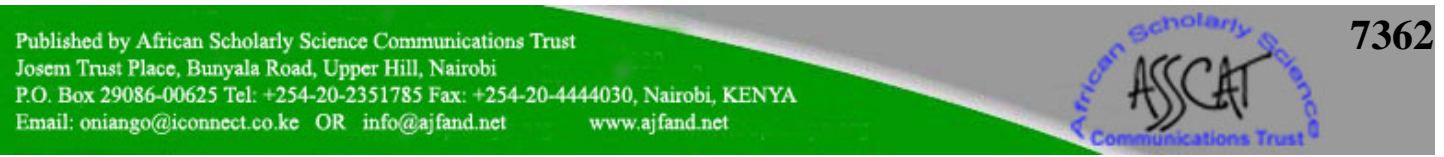




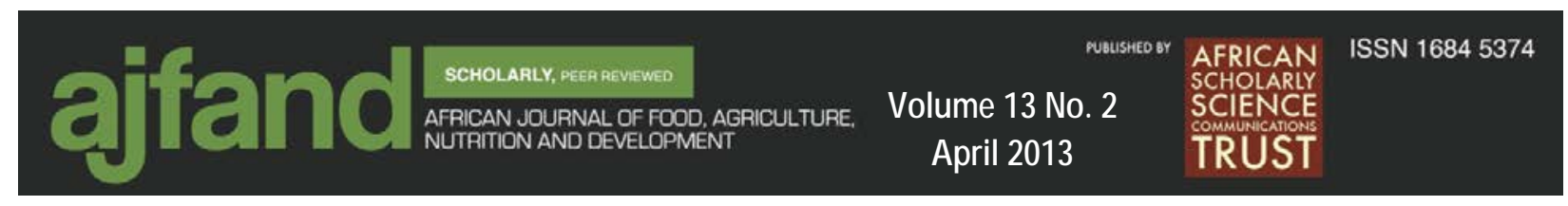

its growth and survivability [8]. The mean birth weight of $21.8 \mathrm{~kg}$ obtained in the present study was lower than the $26.9 \mathrm{~kg}$ reported for the breed at the Amrahia dairy farm in the Accra Plains [9]. The variation could be attributed to differences in system of management on the two farms. The crossbred cows on the Amrahia dairy farm were zero grazed with Panicum maximum and supplemented with a concentrate mixture based on maize, wheat bran, palm kernel cake and soybean meal, while those on the ARI Katamanso station were grazed on natural pasture alone. The limited availability and poor quality of forages for the grazing cows especially during the dry season may adversely influence their nutritional status, subsequently affecting the availability of nutrients for foetal development. This is because birth weight is a consequence of the net supply of nutrients reaching the foetus, which is influenced by factors including maternal nutrition, parity of the dam, litter size and foetal and maternal genotype $[10,11]$.

Also, nutrition of cows especially in the last trimester of pregnancy is known to affect birth weight [12]. The mean birth weight recorded in this study was lower than the $31.0 \mathrm{~kg}$ reported for Holstein-Friesian calves on the Accra Plains [13]. It was, however, slightly higher than the $19.2 \mathrm{~kg}$ reported for Sanga calves in the same ecozone [5]. This might be due to differences in maternal genotype, the HolsteinFriesian being a heavier breed than the Sanga. The male calves were 5.3\% heavier at birth than their female counterparts. This could be attributed to the greater rate of skeletal growth in utero of male calves compared to female calves [14].

The recorded average weaning weight of $94.2 \mathrm{~kg}$ was higher than $80.1 \mathrm{~kg}$ obtained for Friesian x Sanga crossbred calves on the same station [5]. The observed slight increase in weaning weight of calf with parity may be attributed to increasing mothering ability, especially increased milk production as parity increased because older cows are better milkers [15]. It has been reported that maternal abilities of cows mostly affect the weaning weights of their calves through the milk they produce [16].

The pre-weaning (from birth to 7 months) average daily gain of $0.33 \mathrm{~kg}$ recorded for calves in this study was higher than the value $0.26 \pm 0.07 \mathrm{~kg}$ reported for the breed on the same station [5]. It was, however, lower than the $0.62 \mathrm{~kg} / \mathrm{day}$ and $0.57 \mathrm{~kg} / \mathrm{day}$ reported for Friesian calves in the Accra Plains and the humid forest zone in Ghana $[13,17]$. The differences may be genetic. The Friesian is a heavy dairy breed with fast growth rate compared with the Sanga, which is a lighter breed with slow growth rate. Calves resulting from mating these two breeds would tend to have lower growth rate than the pure-bred Holstein-Friesian.

\section{Weight of calf at 12 and 18 months, and post-weaning average daily gains}

The average post-weaning (7-12 months) daily gain of calf was $0.23 \pm 0.03 \mathrm{~kg}$ and was comparable to the value of $0.21 \pm 0.03 \mathrm{~kg} /$ day obtained by Sottie et al. [5]. The post-weaning average daily gain recorded in the present study was lower than the preweaning average daily gain $(0.33+0.02 \mathrm{~kg}$; from birth to 12 months). This might be due to the shock calves might have experienced during the process of weaning.

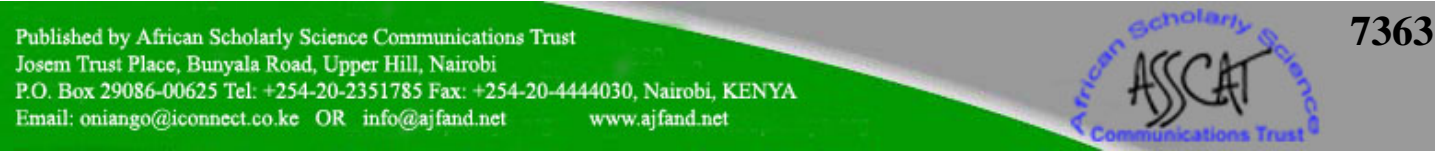




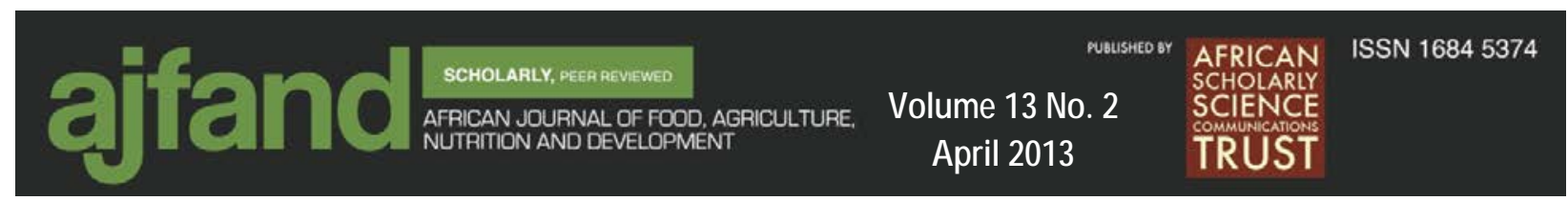

Maternal influence diminishes after weaning. From there on, growth of the calf depends highly on the interactions between its genotype and the surrounding environment, especially nutrition and health [18].

\section{Age at first calving and calving interval}

Reproduction plays a major role in the productive efficiency in cattle. The productive life of a cow is an indication of her utility and is influenced by factors including age at first calving and calving interval [19]. The mean age at first calving was delayed, 41.2 \pm 1.2 months. Nutritional stress, both seasonally and in the long term leading to massive fluctuations in weight and overall slow growth rates could have delayed the age at first calving in these animals. Nutrition is known to determine pre-pubertal growth rates, reproductive organ development, and onset of puberty and subsequent fertility in cattle.

The mean age at first calving compared favourably with the 42.8 months obtained for Africander; a Sanga breed in Mozambique [20]. It was, however, higher than the 33.5 months reported for the Friesian x Sahiwal crossbred in Pakistan [21].

Maintaining yearly calving intervals is essential for profitability of beef and dairy enterprises [22]. The main determinant of calving intervals is the post-partum anoestrous interval which is the period after calving before normal ovarian cycles are re-established [23]. The duration of post-partum anoestrus is influenced by a number of factors including nutritional status, suckling, periparturient disease (Ketosis, mastitis, retained placenta, metritis), season of calving, breed, and age or parity of cow [24, 25]. To achieve a calving interval of 365 days (12 months), a postpartum cow has to resume ovulation and oestrus, be inseminated, and conceive within 85 days of calving [26]. The calving interval of 441.6 days recorded in this study was prolonged compared to the 365 to 420 days period considered acceptable for tropical cattle [27]. Cows in the present study grazed mainly on natural pastures and were not supplemented with either crop residues, agro-industrial by-products or energy or protein concentrates. During the dry season, the limited pasture available on the Accra plains is of poor quality, protein levels are low and the grasses become fibrous and highly lignified affecting their digestibility. Thus, the nutrition of cows might be inadequate during periods when feed resources are scarce and of poor quality. This might have, adversely, affected the synthesis and secretion of hormones responsible for ovarian follicular development and function leading to extended calving intervals in these cows $[28,29]$. The inadequate intake of nutrients relative to metabolic demands have been reported to contribute to prolonged post-partum anoestrus in tropical cows depending on natural forages for most or all of their feed requirements [30]. Poor nutritional status in cows reduces concentrations of luteinising hormone $(\mathrm{LH})$, insulin-like growth factor-1 and oestradiol in the plasma, resulting in delay in occurrence or decrease in the magnitude of the ovulatory surge of LH induced by oestradiol, leading to anovulation [31]. 


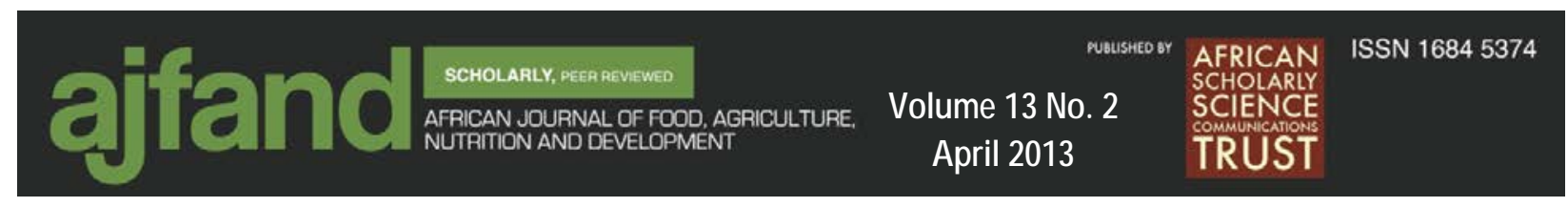

The mean calving interval obtained in this study was, however, lower than the 510. 3 days reported for the same breed on the Amrahia dairy farm where artificial insemination was being practiced [9]. The interval from calving to conception ("days open") was prolonged in the cows on that farm and this may have contributed to the extended calving interval. Parity of dam influenced calving interval, with primiparous cows having the longest calving interval in the present study. This could be attributed to the fact that these first-time calvers were still growing and might have competed severely with the foetuses they carry, for available nutrients for their growth and maintenance during pregnancy. This could, adversely, influence foetal growth and development during gestation, thus extending the calving interval. First parity Friesian-Sahiwal crossbred cows have also been observed to have prolonged calving intervals than older cows as a result of prolonged post-partum anoestrous periods [22].

\section{CONCLUSION}

The growth and reproductive performance of Friesian x Sanga crossbred cattle in the present study was less than optimum, and characterized by low birth weight, slow growth rate, and prolonged age at first calving and calving interval. Focusing on environmental factors, especially improving the nutrition of the animals and also ameliorating the unfavorable effects of heat stress could enhance productivity in the Friesian $x$ Sanga crossbred. For example, the diets of these grazing cattle could be supplemented with energy and/or protein concentrates that would increase the energy and/or protein supply to these animals for improved performance. Also, grazing the cattle during periods in the day when environmental temperatures are not too high especially early in the morning and late evening should reduce heat stress and improve feed intake in these animals. 
Table 1: Sex, parity and season of calving effects on pre-weaning growth traits of Friesian $x$ Sanga calves (Least squares means \pm standard error )

$\mathrm{N}$ Birth weight $\mathrm{N}$ Weaning weight $\mathrm{N}$ Pre-weaning $(\mathrm{kg})$ $(\mathrm{kg})$ growth rate (kg/day)

Overall
$5121.8 \pm 0.5$
51
$94.2 \pm 3.8$
$50 \quad 0.33 \pm 0.02$

Sex

$\begin{array}{lrrrrrr}\text { Male } & 24 & 22.5 \pm 0.8 & 24 & 92.2 \pm 5.5 & 23 & 0.32 \pm 0.03 \\ \text { Female } & 27 & 21.3 \pm 0.8 & 27 & 100.3 \pm 5.5 & 27 & 0.36 \pm 0.02\end{array}$

\section{Parity}

1

$17 \quad 20.5 \pm 0.9$

17

$86.9 \pm 6.4$

$16 \quad 0.30 \pm 0.03$

2

$10 \quad 22.6 \pm 1.2 \quad 10$

$87.2 \pm 8.6$

$10 \quad 0.30 \pm 0.04$

3

$11 \quad 21.2 \pm 1.1 \quad 11$

$114.9 \pm 8.2$

$11 \quad 0.42 \pm 0.04$

4

$13 \quad 23.1 \pm 1.0 \quad 13$

$95.9 \pm 7.4$

$13 \quad 0.34 \pm 0.03$

Season of calving

$\begin{array}{lrrrrrr}\text { Major } & 21 & 21.4 \pm 0.8 & 21 & 92.3 \pm 5.8 & 21 & 0.32 \pm 0.03 \\ \text { Minor } & 12 & 21.1 \pm 1.1 & 12 & 105.8 \pm 8.03 & 11 & 0.39 \pm 0.04 \\ \text { Dry } & 18 & 23.1 \pm 0.9 & 18 & 90.5 \pm 6.26 & 18 & 0.31 \pm 0.03\end{array}$

$\mathrm{N}=$ number of records 
Table 2: Sex, parity and season of calving effects on post-weaning growth traits of Friesian $x$ Sanga calves (Least squares means \pm standard error)

\begin{tabular}{|c|c|c|c|c|c|c|}
\hline & $\mathrm{N}$ & $\begin{array}{l}\text { Weight at } 12 \\
\text { months (kg) }\end{array}$ & $\mathrm{N}$ & $\begin{array}{l}\text { Weight at } 18 \\
\text { months (kg) }\end{array}$ & $\mathrm{N}$ & $\begin{array}{l}\text { Post-weaning } \\
\text { growth rate } \\
\text { (kg/day) }\end{array}$ \\
\hline Overall & 48 & $128.0 \pm 3.4$ & 26 & $159.9 \pm 4.5$ & 46 & $0.23 \pm 0.03$ \\
\hline \multicolumn{7}{|l|}{ Sex } \\
\hline Male & 20 & $126.3 \pm 5.2$ & 24 & $151.4 \pm 13.0$ & 19 & $0.23 \pm 0.04$ \\
\hline Female & 28 & $135.5 \pm 4.6$ & 27 & $164.3 \pm 8.4$ & 27 & $0.21 \pm 0.03$ \\
\hline \multicolumn{7}{|l|}{ Parity } \\
\hline 1 & 17 & $122.2 \pm 5.5^{\mathrm{a}}$ & 17 & $157.4 \pm 9.6$ & 16 & $0.22 \pm 0.04$ \\
\hline 2 & 9 & $135.2 \pm 7.8^{\mathrm{ab}}$ & 10 & $148.3 \pm 13.4$ & 9 & $0.25 \pm 0.05$ \\
\hline 3 & 10 & $125.0 \pm 7.1^{\mathrm{ab}}$ & 11 & $162.4 \pm 13.8$ & 9 & $0.20 \pm 0.05$ \\
\hline 4 & 12 & $141.2 \pm 6.6^{\mathrm{b}}$ & 13 & $163.3 \pm 11.7$ & 12 & $0.24 \pm 0.04$ \\
\hline \multicolumn{7}{|c|}{ Season of calving } \\
\hline Major & 22 & $120.8 \pm 4.8$ & 21 & $148.8 \pm 6.9$ & 7 & $0.17 \pm 0.03$ \\
\hline Minor & 11 & $145.7 \pm 7.1$ & 12 & $154.0 \pm 23.6$ & 1 & $0.23 \pm 0.04$ \\
\hline Dry & 15 & $126.1 \pm 6.0$ & 18 & $170.7 \pm 7.4$ & 5 & $0.26 \pm 0.04$ \\
\hline
\end{tabular}

Means in the same column with different superscripts (a,b) are significantly different $(\mathrm{P}<0.05)$

$\mathrm{N}=$ number of records 
Table 3: Age at first calving and calving interval of Friesian $x$ Sanga cows (Least Squares means \pm standard error)

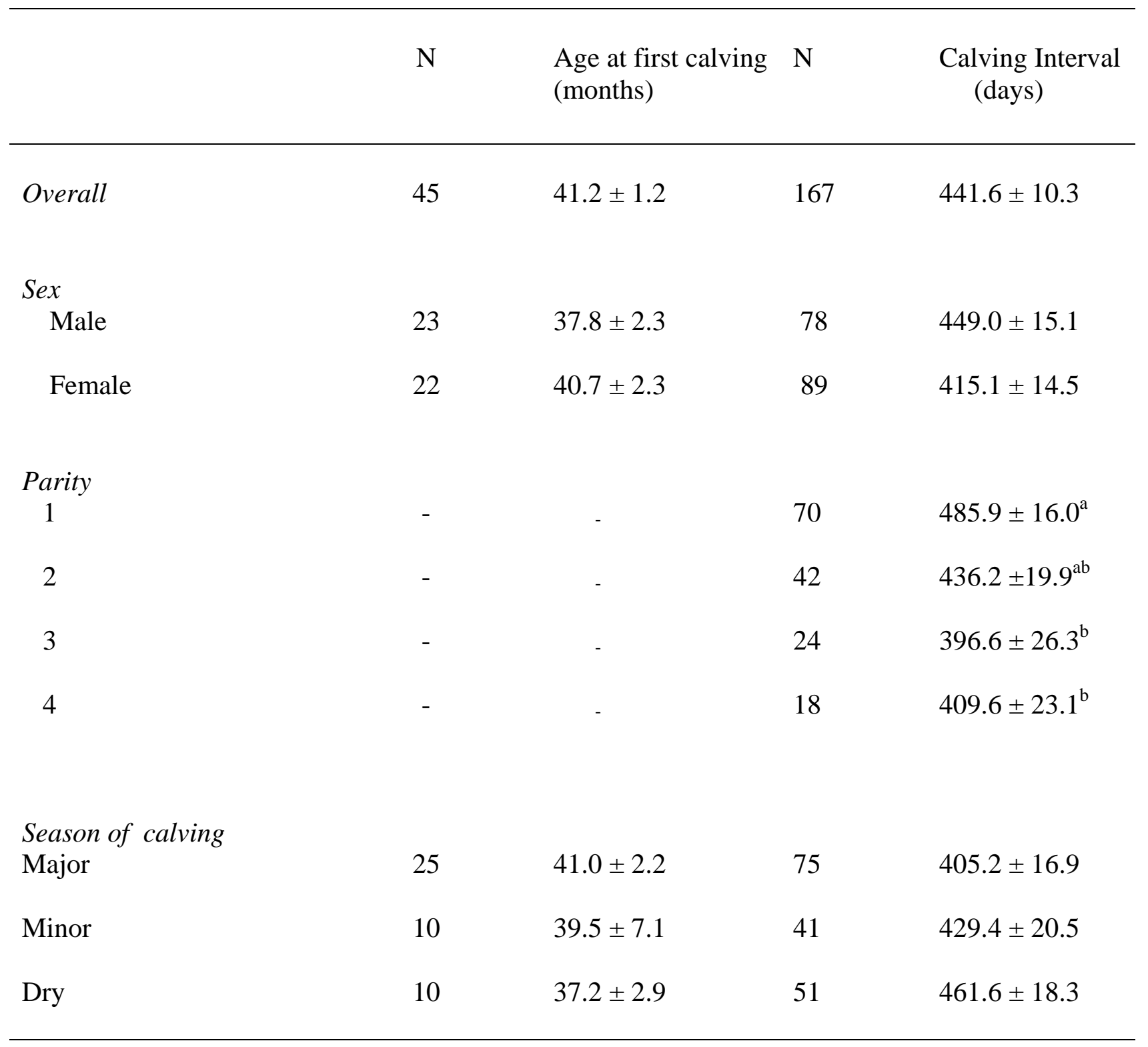

Means in the same column with different superscripts (a,b) are significantly different $(\mathrm{P}<0.05)$ $\mathrm{N}$ = number of records 


\section{REFERENCES}

1. Okantah SA, Obese FY, Oddoye EOK, Gyawu P and Y Asante A survey on the livestock and milk production characteristics of peri-urban agropastoral dairying in Ghana. Gh. J. Agric. Sci.1999; 32: 39-46.

2. Okantah SA, Obese FY, Oddoye EOK, Karikari PK, Gyawu P and MJ Bryant The effect of farm (herd) and season of calving on the reproductive performance of Sanga cows in smallholder peri-urban dairy farms in the Accra Plains. Gh. J. Agric. Sci, (NARS Edition 1) 2005; 1: 37-42.

3. Obese FY, Okantah SA, Oddoye EOK and P Gyawu Post-partum reproductive performance of Sanga cattle in small-holder peri-urban dairy herds in the Accra plains of Ghana. Trop. Anim. Hlth. Prod. 1999; 31: 181190.

4. Kabuga JD The dairy industry in Ghana: Retrospect and prospects. Proceedings of the $2^{\text {nd }}$ Annual General Meeting of Ghana Society of Animal Production. University of Ghana, Legon, 1989: pp 1- 26.

5. Sottie ET, Darfour-Oduro KA and SA Okantah Comparative studies on growth traits of Sanga and Friesian-Sanga crossbred calves raised on natural pasture on the Accra Plains of Ghana. Trop. Anim. Hlth. Prod. 2009; 41: 321328.

6. Oddoye EOK, Amaning-Kwarteng K, Fleischer JE and EK Awotwi Response of calves to dry season supplementation of urea-ammoniated rice straw or untreated rice straw fed with Griffonia simplicifolia or wheatbran. Bull. Anim. Hlth. Prod. Afr. 2002; 50: 96-105.

7. SAS 1999 SAS/STAT Guide for Personal Computers, version 6 (Statistical Analysis Systems Institute, Cary, NC).

8. Rastogi R K and F G Yousef F G Notes on early growth rates of lambs of some tropical breeds. Anim. Breed. Abstr. 1979; 47:722 (Abstract).

9. Obese FY, Dafour-Oduro KA, Gomda Y and E Bekoe Reproductive Performance following Artificial Insemination in Sanga and Crossbred (Friesian x Sanga) Cows in the Accra Plains of Ghana. In: Odongo NE, Garcia $M$ and GJ Viljoen (Eds). Sustainable Improvement of Animal Production and Health. FAO/IAEA Division of Nuclear Techniques in Food and Agriculture, IAEA, Vienna, Austria, 2010; pp 201-203.

10. Holland M D and K G Odde Factors affecting calf birth weight: a review. Theriogenolgy 1992; 38: 769-798. 
11. Greenwood PL, Café LM, Hennessy $D$ W and $H$ Hearnshaw Consequences of nutrition and growth retardation early in life for growth and composition of cattle and eating quality of beef. Recent Adv. Anim. Nutr. Australia 2005; 15:183-195.

12. Oddoye E O K, Okantah S A, Obese F Y and P Gyawu Growth performance, body condition score and milk yield of Sanga cattle in smallholder peri-urban dairy herds in the Accra Plains of Ghana. Bull. Anim. Hlth. Prod. Afr. 1999; 50:143-148.

13. Hagan R D Feeding of dairy cattle at Amrahia Dairy Farm. Proceedings of the $9^{\text {th }}$ Ghana Animal Science Association Symposium. Department of Animal Science, Kwame Nkrumah University of Science and Technology, Kumasi, Ghana, March 31 - April 1 1977; pp 62-66.

14. Tuah AK and YN Danso Preliminary studies on the performance and productivity indices of N'dama and West African Shorthorn cattle in Ghana Trop. Anim. Hlth. Prod. 1985; 17: 114-120.

15. Eltawil LA, Hazel LN, Sidwell GM and CE Terrill Evaluation of environmental factors affecting birth, weaning and yearling traits in Navajo sheep. J. Animal Sci. 1970; 31: 823-827.

16. Kock RM The role of maternal effect in animal breeding VI. Material effects in beef cattle. 1972; J. Anim. Sci. 35: 316.

17. Gyawu $\mathbf{P}$ and K Agyemang The performance of a herd of Holstein-Friesians in the humid tropical forest zone of Ashanti, Ghana. Proceedings of Ghana Animal Science Association. 1977; 12-19.

18. Holloway JW, Warrington BG, Forest DW and DR Randel Preweaning growth of F1 tropical adapted beef cattle breeds cross with Angus and reproductive performance of their dams in and rangeland. J. Anim. Sci. 2002; 80: $911-918$.

19. Hossein-Zadeh GN Estimation of genetic and phenotypic relationships between age at first calving and productive performance in Iranian Holsteins. Trop. Anim. Hlth. Prod. 2011; 43: 967-973.

20. Carvalheira JG, Blacke R W, Pollak E and P Van Soest comparison of Landim and africander cattle in southern Mozambique body weights and growth. J. Anim. Sci. 1995; 73: 3519-3526.

21. Rafique M, Chaudhry MZ and MA Amer Reproductive performance of inter se H. Friesian x Sahiwal crossbred. Paskistan Vet. J 2000; 20 :109 -112. 
22. Mihm M Delayed resumption of cyclicity of postpartum dairy and beef cows Reprod. Dom. Anim. 1999; 34: 277- 284.

23. Eduvie $\mathbf{L} \mathbf{O}$ and EO Oyedipe Improving the management of reproduction of indigenous cattle in the semi-arid and sub-humid zones of West Africa. In: Isotope and Related Techniques in Animal Production and Health. IAEA,Vienna, 1991; pp 317-340.

24. Mukasa- Mugerwa E A review of reproductive performance of female Bos indicus (zebu) cattle. ILCA monograph No 6 Addis Ababa Ethiopia 1989; pp $1-134$.

25. Rhodes FM and SR Morgan Milk production and production worth of anoestrus dairy cows compared with their cycling herd mates. Proceedings of $59^{\text {th }}$ Conference of the New Zealand Society of Animal Production. Dunedin, New Zealand, June 28 - July1 1999; pp 208-210.

26. Stagg K, Diskin MG, Sceenan JM and JF Roche Follicular development in long-term anoestrus suckler beef cows feed two levels of energy post-partum. Anim. Reprod. Sci. 1995; 38:49-61.

27. Aboagye GS Phenotypic and genetic parameters in cattle populations in Ghana. A review paper presented to International Livestock Research Institute (ILRI), Addis Ababa, Ethiopia. 2002. http://agtr.ilri.cgiar.org/casestudy/caseAboagye-1/casestudy-Aboagye-1.htm Accessed 27th July 2011.

28. Diskin M G, Mackey D R, Roche J F and J M Sreenan Effects of nutrition and metabolic status on circulating hormones and ovarian follicle development in cattle. Anim. Reprod. Sci. 2003; 78: 345-370.

29. Thatcher WW, Bilby TR, Bartolome JA, Silvestre F, Staples CR and JEP Santos Strategies for improving fertility in the modern dairy cow. Theriogenology 2006; 65: 30-44.

30. Jolly PD, McDougall S, Fitzpatrick LA, Macmillan KL and KW Entwistle Physiological effects of under nutrition on postpartum anoestrus in cows. $J$. Reprod. Fertil. (supplement) 1999; 49: 477- 492.

31. Peter AT, Vos PLAM and DJ Ambrose, 2009. Postpartum anestrus in dairy cattle. Theriogenology 2009; 71: 1333-1342. 